\section{THE ROLE OF FAMILY IN HANDLING \\ NEGATIF EMOTION AND \\ CHARACTER BUILDING OF EARLY \\ CHILDHOOD}

\author{
PERAN KELUARGA DALAM \\ MENANGANI EMOSI NEGATIF DAN \\ PEMBENTUKAN KARAKTER ANAK \\ USIA DINI
}

Jurnal Pendidikan Luar Sekolah

http://kolokium.ppj.unp.ac.id/ Jurusan Pendidikan Luar Sekolah

Fakultas IImu Pendidikan

Universitas Negeri Padang

Sumatera Barat, Indonesia

Volume 7, Nomor 1, April 2019

DOI: $10.24036 /$ kolokium-pls.v7i1.24

\author{
Sri Murni ${ }^{1,2}$ \\ ${ }^{1}$ STKIP PGRI Bandar Lampung \\ 2Email: srimurni0905@gmail.com
}

\begin{abstract}
Emotional development of children at an early age needs to get the right stimulation and handling according to the stage of development, the role of the family is very influential on the development of emotions both positive emotions and negatif emotions, because the role is very important parents need to recognize emotions themselves before introducing, managing, motivating, and teach children to recognize the emotions of others, giving stimulation and appropriate actions to deal with the emotions that children show early on will determine the character of the child in the future parents can develop children's emotions through routine activities carried out at home and parents must understand the importance of experience for early childhood.
\end{abstract}

Keywords: Family, Negatif Emotions, Character Formation, Early Childhood

\begin{abstract}
ABSTRAK
Perkembangan emosi anak pada usia dini perlu mendapatkan stimulasi dan penanganan yang tepat sesuai dengan tahap perkembanganya, peran keluarga sangat berpengaruh terhadap perkembangan emosi baik itu emosi positif maupun emosi negatif, karena peranannya yang sangat penting orang tua perlu mengenali emosi dirinya sendiri sebelum mengenalkan, mengelola, memotivasi, dan mengajarkan anak untuk megenal emosi orang lain, pemberian stimulasi dan tindakan yang tepat dalam menghadapi emosi yang ditunjukan anak sejak dini akan menentukan karakter anak dimasa yang akan datang orang tua dapat mengembangkan emosi anak melalui kegiatan rutin yang dilakukan di rumah dan orang tua harus memahami pentingnya pengalaman bagi masa awal kanak-kanak..
\end{abstract}

Kata Kunci: Keluarga, Emosi Negatif, Pembentukan Karakter, Anak Usia Dini 


\section{PENDAHULUAN}

Anak usia dini merupakan anak dalam rentan usia 0-8 tahun atau lebih dikenal dengan masa golden age karena pada masa ini anak mengalami masa peka dan sangat kritis terhadap sesuatu, selain itu pada priode ini khususnya 3-6 tahun banyak orang tua yang mengasumsikan bahwa ini adalah "usia sulit" bagi anak karena mereka akan mengalami berbagai masalah. Pertumbuhan dan perkembangan anak yang berkembang sangat pesat sehingga anak perlu diberikan perhatian, stimulasi, dan penanganan yang tepat sesuai dengan tahap tumbuh kembang anak baik pada aspek pengembangan nilai agama dan moral, kognitif, bahasa, sosial-emosional, fisik-motorik, seni, dan keterampilan.

Pendidikan anak usia dini merupakan dasar pembentukan kepribadian manusia, seperti mengajar bagaimana bersikap sopan dalam kehidupan sehari-hari. Pembentukan kepribadian anak dari usia dini sangat memengaruhi karakter dan kepribadian anak dalam kehidupan sosial dalam masyarakat berdasarkan penelitian yang telah dilakukan oleh Alicia Benavides-Nieto berkata bahwa kehidupan sosialisasi tertinggi berawal dari pembentukan karakter yang dilakukan sejak (Gunawan, 2017).

Taman kanak-kanak merupakan salah satu lembaga pendidikan yang menekankan pertumbuhan dan perkembangan fisik motorik, kompetensi sosial, emosional, bahasa, kognitif, seni, keterampilan, yang disesuaikan dengan keunikan dan tahap perkembangan masing-masing anak sehingga taman kanak-kanak perlu menciptakan lingkungan yang kondusif, nyaman, dan aman bagi anak (Nurhafizah \& Moh.Kosnin, 2017).

Dalam mengembangkan semua aspek pertumbuhan dan perkembangan anak Orang tua juga mengambil peranan yang sangat penting terutama dalam aspek perkembangan emosi anak, sebab waktu anak bersama orang tua atau keluarga lebih lama dibandingkan dengan guru di sekolah sehingga anak akan menirukan apa yang dilihat, didengar, dirasakan, dan yang dialami di rumah. Pada saat ini banyak dari pendidik termasuk orang tua ingin mengurangi waktu anak bermain baik itu di sekolah maupun dirumah karena pendidik dan orang tua berasumsi bahwa ketika anak bermain tidak ada hasil yang diperoleh anak, namun bermain adalah aktivitas yang sangat penting bagi perkembangan anak, anak membutuhkan bagaimana belajar bertahan hidup, mengendalikan perhatian, mengendalikan emosi yang diperoleh dari bermain (Hazizah, 2018).

Selain itu pada priode ini lingkungan yang paling berpengaruh terhadap kepribadian anak adalah keluarga terutama ibu, besarnya pengaruh keluarga menjadi hal paling menarik untuk diperhatikan baik bagi ibu muda maupun calon ibu yang semestinya memahami terlebih dahulu bagaimana karakteristik perkembangan anak termasuk pola perkembangan emosinya agar dapat memberikan stimulasi dan penanganan yang tepat.

Menurut Prawitasllri (1995) emosi merupakan keadaan psikis seseorang yang disampaikan melalui ekspresi atau tindakan. Emosi juga sering diartikan sebagai mood atau perasaan seseorang yang dapat dilihat dari raut wajah, perkataan, tulisan, dan tindakan seseorang. Kecerdasan emosi merupakan kecerdasan yang harus dimiliki oleh seseorang dan harus berkembang dengan baik sebab seseorang yang memiliki kecerdasan emosi mampu menempatkan dan mengendalikan emosi yang dimiliki, oleh sebab itu kecerdasan emosi harus distimulasi sejak dini.

Terdapat beberapa aspek utama dalam perkembangan sosial emosional, yaitu (1) empati seperti penuh pengertian, tenggang rasa, dan kepedulian terhadap sesama, (2) aspek 
afiliasi seperti komunikasi dua arah atau hubungan antar pribadi, kerja sama, dan (3) resolusi konflik seperti penyelesaian konflik, dan (4) aspek pengembangan kebiasaan positif seperti tata krama, kesopanan, dan tanggung jawab (Ananda \& Fadhilaturrahmi, 2018).

Keluarga adalah salah satu faktor penting dalam pengembangan emosi anak, baik itu mengembangkan emosi positif yang dimiliki anak serta penanganan emosi negatif anak yang menentukan terciptanya karakter anak, kememampuan keluarga terutama orang tua untuk mengerti, mendeteksi, menstimulasi, dan memberikan penanganan yang tepat sangat dibutuhkan (Ismaniar \& Sunarti, 2018). Orang tua yang semestinya memahami berbagai macam karakteristik anak dan aspek utama dalam pengembangan emosi anak, pada kenyataannya banyak kita temukan di lapangan bahwa orang tua masih belum memahami perannya sebagai orang tua, sehingga pertumbuhan dan perkembangan anak tidak terstimulasi dengan baik bahkan memperburuk keadaannya, sehingga berpengaruh pada watak dan karakter anak di masa yang akan datang.

Selain itu kurangnya pengetahuan orang tua dalam menangani emosi yang dimunculkan anak ditambah dengan lingkungan keluarga yang tidak mengerti akan tugastugas perkembangan anak secara keseluruhan membuat orang tua kehilangan pedoman dalam menyelesaikan permasalahan emosi yang dialami anak. Menurut Thompson dan Lagattuta (dalam Mashar, 2011) Ppngalaman dan hubungan dalam keluarga sangat berpengaruh terhadap perkembangan emosi anak usia dini yang juga akan berdampak pada terbentuknya karakter anak pada saat dewasa, aktivitas keseharian yang ada di lingkungan keluarga dan hubungan keluarga membuat anak belajar emosi baik penyebab maupun konsekuensinya.

\section{KAJIAN TEORI}

Menurut Crow \& Crow (dalam Susanto, 2012) Emosi merupakan watak seperti perasaan, minat, sikap, dan nilai yang dimiliki oleh seseorang yang disertai penyesuaian diri dalam diri seseorang mengenai keadaan mental dan fisik yang dapat dilihat dari suatu perilaku atau tindakan yang ditampilkan oleh individu. Selanjutnya Santrock (2007) menyatakan dalam proses perngembangan sosial-emosional melibatkan adanya perubahan dalam hubungan individu satu dengan individu yang lain, baik itu perubahan emosi, dan perubahan dalam kepribadian.

Menurut David W. Johnson (dalam Nurhafizah \& Moh.Kosnin, 2017) Kompetensi sosial-emosional adalah kemampuan untuk membangun dan mempertahankan hubungan baik dengan orang lain, sikap, dorongan dari luar, dan mengenai apa yang harus dilakukan serta keterampilan seseorang untuk berkomunikasi dengan jelas dan efektif, dan keterampilan membentuk sebuah hubungan yang efektif. Orang tua dan keluarga, guru, serta teman sebaya memiliki peranan yang sangat berpengaruh dalam tercapainya aspek perkembangan sosialemosional anak yang baik pada masa kanak-kanak menurut Boyd (dalam Soetijiningsih, 2012).

Pada saat sekarang ini masih banyak orang tua dan keluarga yang tidak memahami bahwa perkembangan sosial-emosional anak dipengaruhi oleh berbagai macam pengalaman yang dialami anak pada masa awal kanak-kanak, mereka masih mempelajari kemampuan ini yang disebabkan oleh keterbatasan kemampuan yang dimiliki anak tetapi harus dimotivasi dan distimulasi terus menerus agar bisa berkembang (Soetijiningsih, 2012). 
Kondisi emosi dikelompokkan menjadi dua bagian yaitu emosi negatif yang terjadi akibat adanya hubungan yang mengancam atau kondisi menyakitkan seperti: marah, kecemasan, rasa malu atau bersalah, kesedihan, kecemburuan, dan jijik, sedangkan emosi positif terjadi akibat adanya suatu keadaan yang menguntungkan seperti reaksi dari kebahagiaan, rasa senang, bangga, cinta, penghargaan, dan perasaan terharu atau belas kasih (Mashar, 2011).

Menurut Prawitasari (dalam Mashar, 2011) emosi positif seperti gembira, bahagia, ceria, dan sabar perlu dikembangkan sejak dini di mana emosi positif diasumsikan membuat orang lebih sehat jasmani dan rohani, sedangkan emosi negatif seperti marah, cemas, bosan, cemburu, dengki, dan sedih biasanya akan memunculkan banyak masalah, kedua emosi ini baik positif maupun negatif dapat diamati dari ekspresi yang dapat dilihat seperti dari raut wajah, gerakan tubuh, tangan, dan bahasa non verbal lainnya.

Terdapat beberapa cara yang dilakukan orang tua dalam memberi stimulasi terhadap kecerdasan emosi anak di antaranya yaitu (1) orang tua harus meninjau kembali dan memperbaiki pola asuh yang diterapkan selama ini kepada anak, dan menerapkan pola asuh yang bertolak belakang dengan kebiasaan yang dilakukan selama ini (2) memberikan perhatian pada tahap-tahap perkembangan kecerdasan emosi (3) melatih anak untuk mengenali emosi diri sendiri dan cara mengelola emosi tersebut serta mengenali emosi orang lain (Mashar, 2011). Pola asuh dapat diartikan sebagai cara yang dilakukan orang tua dalam mendidik dan merawat anak, kemampuan orang tua dalam mengolah emosi dengan baik pada diri sendiri dan orang lain dan pola asuh yang tepat merupakan hasil darisebuah ikatan perkawinan yang sah yang dapat membentuk keluarga yang memiliki kecerdasan sosialemosional yang baik (Robbiyah, Ekasari, \& Witarsa, 2018).

Ada beberapa hal yang perlu diperhatikan dalam mengembangkan emosi anak yang perlu dipahami oleh orang tua yaitu (1) usia anak, setiap anak memiliki perkembangan emosi yang berbeda di antara anak satu dengan yang lain (2) perubahan emosi dalat dilihat dari ekspresi raut muka yang diperlihatkan (3) anak biasanya menunjukan emosi yang kompleks dalam beberapa waktu (4) bahasa tubuh (5) suara dan perkataan (6)representasi simbolik (7) pengetahuan emosi (8) respon pada perasaan lain (9) tahap-tahap perkembangan emosional (10) ikatan emosional dengan yang lain (11) menempatkan perubahan emosi (Nurmalitasari, 2015)

Peran keluarga dalam membantu anak mengatasi hambatan yang berhubungan dengan perkembangan sosial-emosional anak (1) pola asuh orang tua, dalam mengembangkan emosi anak orang tua harus disesuaikan dengan keadaan dan situasi, adakalanya orang tua menerapkan pola asuh otoriter, demokratis, dan permisif (2) perlakuan orang tua kepada anak sebaiknya disesuaikan dengan tahap perkembangan anak, dan usia anak (Soetijiningsih, 2012).

Kecerdasan emosi sangat penting di kembangkan dan distimulasi sejak dini, anak yang kecerdasan emosi baik terlihat bahagia, bermotivasi tinggi, orang tua yang mengambil peran terbesar harus terlebih dahulu memiliki kecerdasan emosi dalam dirinya sebelum mengembangkan kecerdasan emosi anak (Mashar, 2011). Anak usia dini sering menunjukan respon emosi yang dapat diamati dan diupayakan pengembangannya yaitu (1) membiarkan dirinya nyaman dalam kondisi tertekan (stress) upaya yang dapat membantu stress yang dialami anak yaitu membacakan buku cerita, memberikan benda yang dapat menstimulasi anak bisa mengungkapkan perasaannya, memberikan mainan besar yang bisa dipeluk, dll. (2) 
memberikan kesempatan anak untuk makan, tidur, dan ketoilet tanpa dipaksa (3) mengatasi situasi yang berubah tiba-tiba secara terkontrol (4) tidak mengungkapkan kemarahan dengan tindakan kekerasan (5) mengatasi anak untuk tidak menghindar dari orang lain (6) memberikan kesempatan anak untuk menunjukan minat atau perhatian terhadap kegiatan (7) membiarkan anak terlihat tersenyum bahagia Menurut Beaty dalam (Susanto, 2012).

Kebutuhan emosional dikembangkan untuk mengontrol konflik dan perbedaan yang ada di mana anak akan berlatih mengendalikannya emosi, serta memberikan respons yang lebih efektif terhadap perilaku yang tidak diinginkan, membuat keputusan yang lebih baik, dan mengembangkan hubungan yang sehat dengan orang lain di masa yang akan datang menurut Glatt dalam (Nurhafizah \& Moh.Kosnin, 2017).

\section{PEMBAHASAN}

Seperti yang telah kita ketahui bahwa anak usia dini berada pada masa priode pertumbuhan dan perkembangannya begitu pesat, perkembangan emosional merupakan salah satu aspek perkembangan anak yang sangat penting diberi stimulasi sejak dini, sebab seperti yang dikatakan Susanto (2012) emosi merupakan perasaan atau watak yang ada dalam diri individu baik keadaan mental maupun fisik. Dalam membantu perkembangan emosi anak terdapat beberapa factor yang memengaruhi emosi anak usia dini baik yang berasal dari dalam diri individu maupun dari lingkungan sekitar. Pada proses perkembangan emosi anak orang tua dan keluarga, guru, serta teman sebaya memiliki peranan yang sangat penting, namun pada kenyataan yang kita temui di lapangan dan dalam kehidupan sehari-hari masih banyak dari orang tua atau keluarga yang belum memahami peranan mereka dalam pengembangan emosi anak seperti yang telah dikemukakan oleh Soetijiningsih (2012) yang mana orang tua dan keluarga yang tidak mengerti bahwa perkembangan sosial emosional anak dipengaruhi oleh pengalaman yang dialami oleh anak pada masa awal kanak-kanak, di mana pengalaman terbesar yang diterima anak berasal dari lingkungan keluarga nya sendiri, di sini seharusnya orang tua telah memiliki pemahaman dan kemampuan dalam menciptakan pengalaman positif anak dalam rangka membantu perkembangan emosi yang positif bagi anak dan mengurangi dampak yang ditimbulkan dari emosi negatif yang ditampilkan anak.

Santrock (2007) mengemukakan bahwa dalam proses perkembangan sosialemosional menginginkan terdapat perubahan baik emosi maupun kepribadian anak, di sini orang tua harus bisa menjalankan peranannya sebaik mungkin agar perkembangan emosional anak berkembang dengan baik dan terjadinya perubahan karakter pada anak di masa yang akan datang. Emosi yang dimiliki dikategorikan menjadi dua yaitu emosi positif dan emosi negatif, yang dapat dilihat dari ekspresi, gerakan tubuh, perilaku, bahasa, dan tindakan yang dilakukan anak seperti yang dikutip oleh Mashar (2011), untuk itu di sini orang tua harus memahami peranannya bagaimana mengembangkan emosi positif dan mengurangi emosi negatif anak atau mengalihkannya menjadi emosi positif, namun hal yang sering kita jumpai bahwa orang tua melakukan penanganan yang tidak terpat terhadap reaksi emosi negatif yang dilihatkan anak sehingga emosi negatif tersebut semakin buruk dan berkembang.

Orang tua dapat mengembangkan emosi positif anak dan menangani emosi negatif anak melalui kegiatan rutin yang dilakukan secara bersama, mengontrol perkataan dan tingkah laku di depan anak, melalui kegiatan bermain dan meluangkan waktu bersama, selain itu orang tua harus memperbaiki kembali pola asuh yang ditetapkan selama ini menjadi lebih baik serta melatih anak untuk mengenali emosi diri dan emosi orang lain serta bagaimana 
mengelola emosi tersebut. Sebagai orang tua ada beberapa hal yang perlu kita perhatikan dalam mengembangkan emosi anak, sebelum itu kita harus bisa terlebih dahulu mengontrol emosi kita sendiri. Adapun hal-hal yang sebaiknya diperhatikan yaitu usia dan tahap perkembangan anak, perubahan emosi yang ditunjukkan anak, bahasa tubuh, suara dan perkataan, dan respond dari stimulasi yang diberikan.

Dalam mengembangkan emosi anak pola asuh orang tua mengambil bagian penting sebab pola asuh yang diterapkan akan berdampak pada pengalaman yang diterima anak sehingga jika pola yang diterapkan hanya otoriter maka akan menggangu perkembangan emosi anak sebagai contohnya anak tidak berani mengemukakan pendapat karena terbiasa menunggu perintah, selain itu orang tua hendaknya juga memperlakukan anak sesuai dengan tahap perkembangannya (Soetijiningsih, 2012).

Jika dilihat dalam kehidupan sehari-hari masih banyak kita temui bahwa orang tua tidak dapat mengelola emosi diri sendiri sehingga memberikan pengalaman yang buruk bagi masa awal anak-anak,sementara kebutuhan anak untuk mendapatkan contoh dan pengalaman harus dipenuhi, dan jika ini terus-terus terjadi akan berdampak buruk terhadap perkembangan emosional anak, karena kecerdasan emosi sangat penting untuk distimulasi sejak usia dini. Di sini terlihat banyaknya orang tua dan keluarga yang tidak memahami bagaimana tindakan yang semestinya dilakukan, banyak orang tua dan keluarga member tekanan kepada anak ketika anak menunjukan reaksi negatifnya seperti ketika anak marah kepada adiknya lalu menunjukan kemarahan tersebut dengan membanting barang, orang tua sering kali kembali memarahi anak tersebut. Hal ini tidak semestinya terjadi sebab orang tua yang memahami keadaan emosi anak akan mencoba meredam amarah tersebut dengan berbagai aktivitas yang dilakukan bersama, serta ketika emosi itu sudah mulai mereda barulah mencari tau alasan dibalik tindakan yang dilakukan anak, lalu kemudian mencarikan solusi dari masalah yang dihadapi anak dan memberikan pemahaman kepada anak mengenai emosi yang ada di dalam diri dan bagaimana cara mengontrolnya.

Orang tua dan keluarga juga seharusnya mengerti dan memahami perubahan emosi yang terjadi pada anak sehingga dapat ditangani dengan cara yang tepat, orang tua dan keluarga hendaknya dapat memberikan rasa nyaman, memberikan kebebasan pada anak dalam menjalankan aktivitasnya dengan adanya pengontrolan, mengatasi mood anak yang berubah dengan tidak menggunakan tindakan kekerasan, membiasakan anak untuk bersosialisasi, serta memberikan anak kesempatan untuk mengembangkan minat dan bakat yang dimiliki. Jika saja orang tua dapat melaksanakan perannya dengan sangat baik maka emosi negatif anak akan dapat ditangani dan emosi positifnya dapat dikembangkan secara optimal sejak usia dini maka akan terbentuklah generasi yang berkarakter di masa yang akan datang.

\section{KESIMPULAN}

Perkembangan emosi anak perlu dikembangkan dan distimulasi sejak usia dini, sebab akan berpengaruh juga terhadap aspek perkembangan lainnya, perkembangan emosi juga ditentukan oleh stimulasi dan tindakan yang dilakukan orang tua dalam menangani reaksi emosi yang ditimbulkan anak, orang tua dan keluarga yang memberikan pengalaman mengenai emosi di masa awal kanak-kanak perlu diperhatikan dan perlu adanya perbaikan dalam menerapkan pola asuh anak dalam keluarga karena perkembangan emosi anak baik itu emosi positif dan negatif tak lepas dari peran orang tua, setiap orang tua dan keluarga 
The Role of Family in Handling Negative Emotion and Character Building of Early Childhood

memiliki kewajiban untuk mengenalkan, mengelola, memotivasi, emosi yang ada pada diri anak dan mengenali emosi yang ada pada oranglain, ini dapat dilakukan melalui kegiatan rutin yang dilaksanakan di rumah dan kegiatan pembiasaan yang mana akan berdampak pada terbentuknya karakter anak di masa yang akan datang. Maka disimpulkan bahwa stimulasi dan penanganan yang tepat terhadap perkembangan emosi baik positif maupun negatif akan berdampak pada karakter anak yang distimulasi sejak dini.

\section{DAFTAR RUJUKAN}

Ananda, R., \& Fadhilaturrahmi, F. (2018). Peningkatan Kemampuan Sosial Emosional Melalui Permainan Kolaboratif pada Anak KB. Jurnal Obsesi: Jurnal Pendidikan Anak Usia Dini, 2(1), 20-26. https://doi.org/10.31004/obsesi.v2i1.3

Gunawan, R. (2017). The Role of Character Education for Early Children in Early Childhood Education Programs in Happy Kids Bogor Indonesia. In Advances in Social Science, Education and Humanities Research (ASSEHR) (Vol. 66, pp. 23-26). Jakarta: Atlantis Press.

Hazizah, N. (2018). The Importance of Playing for Developing Intelligence in Early Childhood. In International Conference of Early Childhood Education (ICECE 2017) (Vol. 169, pp. 213-215).

Ismaniar, I., \& Sunarti, V. (2018). Buku Ajar Pelatihan Parenting. (A. H. Pamungkas, Ed.). Padang: Penerbit Jurusan Pendidikan Luar Sekolah Fakultas Ilmu Pendidikan Universitas Negeri Padang.

Mashar, R. (2011). Emosi Anak Usia Dini dan Strategi Pengembangannya. Jakarta: Prenamedia Group.

Nurhafizah, \& Moh.Kosnin, A. (2017). The Development of Children's Social-Emotional Competences: A Case Study in UNP's Labschool-Kindergarten, Padang Indonesia. In Advances in Social Science, Education and Humanities Research (ASSEHR) (Vol. 58, pp. 369-374). Padang: Atlantis Press.

Nurmalitasari, F. (2015). Perkembangan Sosial Emosi pada Anak Usia Prasekolah. Buletin Psikologi, 23(2), 103-111.

Prawitasllri, J. E. (1995). Mengenal Emosi Melalui Komunikasi Nonverbal. Buletin Psikologi, III(1). Retrieved from https://journal.ugm.ac.id/buletinpsikologi/article/viewFile/13384/9598

Robbiyah, Ekasari, D., \& Witarsa, R. (2018). Pengaruh Pola Asuh Ibu terhadap Kecerdasan Sosial Anak Usia Dini di TK Kenanga Kabupaten Bandung Barat. Jurnal Obsesi: Jurnal Pendidikan Anake Usia Dini, 2(1), 76-84. https://doi.org/10.31004/obsesi.v2i1.10

Santrock, J. (2007). Perkembangan Anak (11th ed.). Jakarta: Erlangga.

Soetijiningsih, K. . (2012). Perkembangan Anak Sejak Pembuahan Sampai dengan Kanak-kanak Akhir. Jakarta: Prenada.

Susanto, A. (2012). Perkemabangan Anak Usia Din, Pengantar dalam berbagai Aspeknya. Jakarta: Prebadamedia Group. 